\title{
Eve Is Not Blamed for the Fall from Eden, Nor Are Women Guilty by Association
}

\section{Qur'anic Verses on the Fall from the Garden}

The Qur'an describes God's creation of the human being and its infusion with His Spirit multiple times, as we have already seen. In 25 other verses the first male, Adam, is referred to by name. Reference is also made to Adam's mate and spouse though her name, Eve (Hawwa' in Arabic, as in Hebrew), is not mentioned. Once again, this is no doubt a reflection of prevailing customs - neither Sarah nor Hagar are mentioned by name in relation to Abraham, for example, and so on.

Importantly, the Qur'an does not single out Eve for blame in the matter of the original couple disobeying God and thus being exiled from the Garden for a time. If anything, the Qur'an actually singles out Adamunsurprising given that he is the representative of humanity with whom God had made His covenant-though the overall message is firm in that both Adam and Eve did wrong of their own free will and were therefore accountable. Thus there is no premise for women to be considered "guilty by association".

There are three groups of verses that show, in an almost identical way, the free will and accountability of both Adam and Eve. I am including them all here to highlight the number of times the Qur'an could have singled out Eve for special blame for the Fall from the Garden, but did not. I also want to show how the Arabic original explicitly addresses both Adam and Eve by using the dual-plural, which does not always come

(C) The Author(s) 2022

L. El-Ali, No Truth Without Beauty, Sustainable Development

Goals Series, https://doi.org/10.1007/978-3-030-83582-8_6 
across in English translations since "you" in English applies to the singular, the dual-plural, and the communal-plural. Also I have underlined some phrases for a reason, which will soon be made clear.

\section{Group 1: The Cow, 2:35-38}

And We said: Oh Adam, dwell with your spouse in the Garden and eat from it freely from whatever you both like but do not approach this tree, either of you, for then you would become wrong-doers.

Then Satan caused them both to slip and removed them from the (ideal) state they were in. And We said: Descend, all of you. You [pl. that denotes three or more] will be enemies to one another. And you shall have a dwelling-place on earth, and enjoyment for a while.

Then Adam received words from his Lord, for He relented towards him. Truly He is the Ever-Relenting, Ever-Merciful.

We said: Descend from it, all of you. But you will surely receive guidance from $\mathrm{Me}$, and those who follow My guidance shall have nothing to fear, nor shall they grieve.

Group 2: The Heights, 7:19-24

Oh Adam, dwell with your spouse in the Garden and eat from whatever you both like but do not approach this tree, either of you, for then you would become wrong-doers.

Then Satan whispered to them both so as to make them aware of their private parts, of which they had not been conscious. And he said: Your Lord has only forbidden you both this tree so you cannot become angels, nor join the immortals.

And he swore to them both: I am your sincere adviser!

Thus he lured them both with delusion. And when they tasted of the tree they became conscious of their private parts, and they went about covering themselves with leaves from the Garden. And their Lord called out to them: Did I not forbid you both this tree, and tell you both that Satan is a clear enemy? 
They both said: Our Lord! We have wronged ourselves. And if You don't forgive us and have mercy on us, we shall surely be lost.

He said: Descend, all of you. You [pl. that denotes three or more] will be enemies to one another. And you shall have a dwelling-place on earth, and enjoyment for a while.

And finally, this is where Adam is singled out for blame, to some extent:

Group 3: Ta Ha (uncertain meaning), 20:115

And We had made a pact with Adam in the past, but he forgot, and We did not find him to be of firm resolve.

...continued in 20:120-123

Then Satan whispered to him saying: Oh Adam, shall I show you the tree of immortality and infinite power?

So they both ate from it and thus their private parts became apparent to them, and they began to cover themselves with leaves from the Garden. Adam disobeyed his Lord, and so he lost his way.

Then his Lord chose him, and relented towards him, and guided him.

He said: Descend from it, both of you-all of you. You [pl. that denotes three or more] will be enemies to one another. But you will surely receive guidance from $\mathrm{Me}$, and then whoever follows My guidance will not lose their way, nor suffer.

Now, an important word on the underlined parts beginning with "Descend" in the verses above.

As briefly mentioned, in Arabic there are two plural forms for "you": the first denotes "two", while the second denotes everything above two, i.e. three or more. So it is always clear whether two people are being addressed, or three or more.

But English translations of these verses usually use "you" without additional clarification as to how many people are being addressed.

The problem with this is that although it is linguistically correct English, it can leave the reader or hearer of verses 2:36 and 7:24 thinking that the 
Qur'an is saying that Adam and Eve, and by extension men and women generally, will be pitted against each other.

Such translations essentially convey those parts of 2:36 and 7:24, which are part of the story of Adam and Eve's Fall from the Garden, as follows:

$\times$ Descend, each of you an enemy to the other / enemies unto one another rather than

$\checkmark$ Descend, all of you. You will be enemies to one another

or some such equivalent, which would have made it easier for the reader to realise that those being addressed are in fact not just Adam and Eve, but Adam and Eve and Satan-as is in fact widely agreed by Qur'anic commentators - as well as Adam and Eve's progeny, by extension. ${ }^{1}$

But I am more concerned about how the other "Descend" verse, 20:123 shown above, is usually translated:

$\times$ Descend from it, both of you together, each of you an enemy to the other / enemies unto one another

rather than

$\checkmark$ Descend from it, both of you-all of you. You will be enemies to one another

In other words, most translations of 20:123 translate the "both" part but not the "all" part of the first sentence, perhaps because it is odd to be addressing "both" and "all" at the same time. On its own this omission is not a big issue given that the last part of this verse does point to all of Adam and Eve's descendants. But once "all of you" is omitted in the first sentence, it becomes necessary to also translate the second sentence on "enemies" as addressing "both" Adam and Eve-or at least ambiguously-rather than absolutely everyone, even though the Arabic is clearly in the communal-plural to correspond to the preceding "all of you".

\footnotetext{
${ }^{1}$ See commentary on 7:24-25 in Nasr, Seyyed Hossein (editor-in-chief) et al. 2015. The Study Quran: A New Translation and Commentary. New York: HarperCollins Publishers, 414.
} 
Again, the problem with these translations' decisions is that they can leave the reader or hearer of 20:123 who is not also aware of the totality of the other verses cited in this section with the possibility of hearing the second sentence as God saying that Adam and Eve - and so their descendants alsowill be naturally pitted against one another by gender, rather than generally.

\section{The Pushback of Alleged hadith on Eve: Guilty and Solely Responsible!}

"Hadith" references to Eve, however, turn the Qur'anic story of Adam and Eve's Fall from the Garden on its head. While the Qur'an faults both parties even as it places a little more emphasis on Adam's guilt-presumably as the representative of humanity as I have noted-multiple and varying hadith references all put the blame squarely on Eve's shoulders, and turn quite speculative after that. By the time the famous hadith-based Qur'anic commentary by Tabari is written in the ninth and tenth centuries, these contradicting and creative hadiths are in such wide circulation that Tabari himself quotes a large number of them in his work even as he frequently expresses reservations about their reliability. ${ }^{2}$ Here is a summary of the environment at the time and the kind of "badiths" he referenced:

....it was the majority opinion of theological experts by Tabari's time that it was only through the woman's weakness and guile that Satan could bring about Adam's downfall...Iblis (Satan)... approached Hawwa' (Eve) with the words: 'Look at this Tree! How good it smells, how good it tastes, how nice its color is!' Hawwa' succumbed, then went to Adam and addressed him with Satan's very words; and Adam ate. Other traditions report that Hawwa' commanded her husband to eat, or that she urged him on by saying: 'I have just eaten of it, and it has not harmed me'. Else, sexual desire or intoxication are made to explain the absence of Adam's rational powers at this critical moment: Satan made Hawwa' appear attractive to Adam, and when he wanted her for his desire, she refused to obey unless he first ate of the Tree, or: she gave him wine, and when he was drunk and his rational faculties had left him, she led him to the Tree and he ate.

...God then put His curse on the woman..., but He did not curse the man, only the earth from which he had been created...[and God] banished

\footnotetext{
${ }^{2}$ Stowasser, Barbara Freyer. 1994. Women in the Qur'an, Traditions, and Interpretation. New York: Oxford University Press Inc., 28.
} 
Adam to a life of want and work...God's curse on the woman, however, was ad personam and severe; it involved the constitution and mental abilities... Because Hawwa' had tempted God's servant and had made the Tree bleed when she picked its fruit, she was condemned to bleed once a month, to carry and deliver her children against her will, and to be often close to death on delivery. God also made the woman foolish and stupid, while He had created her wise and intelligent. "Were it not for the calamity that afflicted Hawwa', the women of this world would not menstruate, would be wise, and would bear their children with ease.' ... On the question of the humans' repentance after their disobedience, some traditions quoted by Tabari indicate that both the man and the woman acknowledged their sin and asked God's forgiveness and mercy, but a larger number of reports specify that the prayer for forgiveness and God's promise of eternal life involved Adam alone. ${ }^{3}$

I believe the above quick tour of the anti-Eve "hadith" reports speaks for itself, as does the fact that such a respected scholar as Tabari had doubted their reliability. But more important is the fact that hadith leaves us with a diametrically opposite impression of Eve as our primordial Grandmother-Jeddah in Arabic, for whom the city is named-and of women's capacity to that given by the Qur'an. To accept these hadith reports, one would have to disregard the Qur'anic narrative on Eve and on women, something surely no believing Muslim would do knowingly.

Open Access This chapter is licensed under the terms of the Creative Commons Attribution 4.0 International License (http://creativecommons.org/licenses/ by $/ 4.0 /$ ), which permits use, sharing, adaptation, distribution and reproduction in any medium or format, as long as you give appropriate credit to the original author(s) and the source, provide a link to the Creative Commons licence and indicate if changes were made.

The images or other third party material in this chapter are included in the chapter's Creative Commons licence, unless indicated otherwise in a credit line to the material. If material is not included in the chapter's Creative Commons licence and your intended use is not permitted by statutory regulation or exceeds the permitted use, you will need to obtain permission directly from the copyright holder.

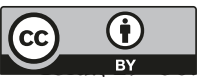

